\title{
PERANAN BADAN USAHA MILIK DESA (BUMDES) DALAM MENINGKATKAN PENDAPATAN MASYARAKAT NELAYAN DESA SUKORAHAYU KECAMATAN LABUHAN MARINGGAI KABUPATEN LAMPUNG TIMUR
}

\author{
${ }^{1}$ Eka Pariyanti, ${ }^{2}$ Fitri Susiani \\ STIE Lampung Timur \\ ekaparianti10@gmail.com
}

\section{FIDUSIA}

Jurnal Ilmiah Keuangan dan Perbankan

ISSN Cetak : 2621-2439

ISSN Online : 2621-2447

Kata Kunci : BUMdes, Pendapatan Masyarakat

\section{ABSTRAK}

BUMDes Desa Sukorahayu mempunyai unit-unit usaha di dalamnya Salah satu diantaranya adalah dengan adanya BUMDes Tirta Kencana yang bergerak di bidang Budidaya keramba, dan kelautan. Kini dengan hadirnya BUMDes warga Sukorahayu sudah tidak kesulitan lagi dalam memenuhi kebutuhan dan keperluan sehari-hari.

Tujuan penelitian ini adalah untuk mengetahui Tujuan penelitian ini adalah untuk Mengetahui bagaimanakah peranan keberadaan BUMDes terhadap pendapatan nelayan desa Sukorahayu.Tekhnik pengumpulan data adalah observasi, wawancara dan Studi pustaka.

Berdasarkan hasil penelitian yang diperoleh peneliti menyimpulkan bahwa peningkatan minimum sebesar Rp 2000.000 sementara data maksimum perubahan peningkatan pendapatan sebesar Rp. 95000000 sementara mean atau data rata rata peningkata pendapatan dengan adanya dana BUMDes sebesar 14.682.926,00. Sementara total peningkatan pendapatan sebanyak Rp. 1.221.000.000 dengan total pinjaman Rp. 813.000.000. dan berdasarkan peningkatan sebesar $53.6 \%$ dari pendapatan sebelum menggunakan dana BUMDes. Sehingga dapat diketahui bersama bahwa keberadaan BUMDes berperan penting dalam meningkatakan pendapatan masyarakat nelayan desa Sukorahayu.

Kata Kunci : BUMdes, Pendapatan Masyarakat 


\section{PENDAHULUAN}

sudah seharusnya eksistensi desa mendapatkan perhatian yang serius dari pemerintah pusat dengan lahirnya kebijakan-kebijakan terkait dengan pemberdayaan ekonomi yang dilakukan dengan cara menghimpun dan melembagakan kegiatan ekonomi masyarakat. Oleh karena itu pemerintah menerapkan pendekatan baru yang diharapkan mampu menstimulus dan menggerakkan roda perekonomian di pedesaan adalah melalui pendirian kelembagaan ekonomi yang dikelola sepenuhnya oleh masyarakat desa yaitu Badan Usaha Milik Desa (BUMDes) sebagai salah satu program andalan dalam meningkatkan kemandirian perekonomian desa. BUMDes lahir sebagai suatu pendekatan baru dalam usaha peningkatan ekonomi desa berdasarkan kebutuhan dan potensi desa.

Pengelolaan BUMDes sepenuhnya dilaksanakan oleh mas yarakat desa, yaitu dari desa, oleh desa, dan untuk desa. Cara kerja BUMDes adalah dengan jalan menampung kegiatan - kegiatan ekonomi masyarakat dalam sebuah bentuk kelembagaan atau badan usaha yang dikelola secara profesional, namun tetap bersandar pada potensi asli desa. Hal ini dapat menjadikan usaha masyarakat lebih produktif dan efektif. Kedepan BUMDes akan berfungsi sebagai pilar kemandirian bangsa yang sekaligus menjadi lembaga yang menampung kegiatan ekonomi masyarakat yang berkembang menurut ciri khas desa dalam rangka meningkatkan kesejahteraan masyarakat desa.

Desa Sukorahayu Kecamatan Labuhan Maringgai Lampung Timur merupakan desa yang sudah mempunyai BUMDes dan telah berjalan selama tiga tahun. Desa Sukorahayu diperoleh dari keuntungan usaha milik desa (BUMDes) Sukorahayu . Pada tahun 2015 keuntungan BUMDes mencapai Rp.54 juta. Angka ini menyumbang hampir seperempat dari pendapatan asli desa. Melihat keberhasilan dari BUMDes Desa Sukorahayu ini menjadikan Desa Sukorahayu sebagai desa yang sering dikunjungi oleh desa lain bahkan desa dari luar Jawa untuk belajar mengenai BUMDes.

BUMDes Desa Sukorahayu mempunyai unit-unit usaha di dalamnya Salah satu diantaranya adalah dengan adanya BUMDes Tirta Kencana yang bergerak di bidang Budidaya keramba, dan kelautan. Kini dengan hadirnya BUMDes warga Sukorahayu sudah tidak kesulitan lagi dalam memenuhi kebutuhan dan keperluan sehari-hari.

BUMDes Desa Sukorahayu selain dalam bidang kelompok nelayan dan kelautan, juga bergerak bidang kredit mikro atau simpan pinjam yaitu Usaha Kredit Mikro (UKM), Jasa Pengelolaan Usaha Desa (JPUD), dan masih banyak unit-unit usaha yang ada di dalamnya namun belum semua berjalan dengan efektif. Pemerintah desa berharap dengan hadirnya BUMDes ini dengan unit - unit usaha yang ada di dalamnya dapat membantu warga dalam meningkatkan kesejahteraan hidupnya melalui pembangunan -pembangunan ekonomi desa secara utuh.

Selain itu semakin majunya BUMDes dikhawatirkan menimbulkan perilaku bisnis bagi pengelolanya yang hanya mengejar keuntungan semata dan melupakan tujuan utama dari BUMDes sendiri yaitu mensejahterakan masyarakatnya. BUMDES Sukorahayu secara 
resmi berdiri pada tahun 2014 dengan sejarah pendirian yang panjang. Pendirian BUMDes Sukorahayu diprakarsai oleh masyarakat desa Sukorahayu kerja sama dengan Pemerintah Kabupaten Lampung Timur. Selanjutnya BUMDes Sukorahayu berkembang dengan pesat dan mampu untuk memberikan Peranan bagi kesejahteraan masyarakat desa.

Berangkat dari titik tolak tersebut penulis merasa perlu untuk mengangkat isu ini sebagai sebuah tema dalam penelitian yang berjudul Peranan Badan Usaha Milik Desa (BUMDes) dalam meninkatkan Pendapatan Masyarakat Nelayan di Desa Sukorahayu Kecamatan Labuhan Maringgai Kabupaten Lampung Timur.

\section{1). Rumusan Masalah}

Berdasrkan uraian diatas peneliti merumuskan masalah yaitu "Bagaimanakah Peranan keberadaan BUMDes dalam meningkatkan pendapatan masyarakat nelayan desa Sukorahayu Kecamatan Labuhan Maringgai Kabupaten Lampung Timur?”

\section{2). Tujuan penelitian}

Tujuan penelitian ini adalah untuk menganalisis peranan Badan Usaha Milik Desa (BUMDes) dalam meningkatkan pendapatan masyarakat nelayan desa Sukorahayu Kecamatan Labuhan Maringgai Lampung Timur.

\section{LANDASAN TEORI}

\subsection{Badan Usaha Milik Desa (BUMDes)}

\subsubsection{Pengertian Badan Usaha Milik Desa (BUMDes)}

Pengertian BUMDes atau Badan Usaha Milik Desa menurut Permendagri No. 39 Tahun 2010 tentang BUMDes adalah usaha desa yang dibentuk/didirikan oleh pemerintah desa yang kepemilikan modal dan pengelolaannya dilakukan oleh pemerintah desa dan masyarakat. Badan Usaha Milik Desa (BUMDES) adalah lembaga usaha desa yang dikelola oleh masyarakat dan pemerintah desa dalam upaya memperkuat perekonomian desa dan dibentuk berdasarkan kebutuhan dan potensi desa.

Menurut UU Nomor 32 Tahun 2004 tentang Pemerintahan Daerah desa dapat mendirikan badan usaha sesuai dengan potensi dan kebutuhan desa. Dijelaskan juga dalam Peraturan Pemerintah Nomor 72 Tahun 2005 tentang Desa bahwa untuk meningkatkan pendapatan desa dan masyarakat, pemerintah desa dapat mendirikan Badan Usaha Milik Desa sesuai dengan kebutuhan dan potensi desa. Hal tersebut berarti pembentukan BUMDES didasar kan pada kebutuhan, potensi, dan kapasitas desa, sebagai upaya peningkatan kesejahteraan masyarakat.

Perencanaan dan pembentukan BUMDES adalah atas prakarsa masyarakat desa. BUMDES didirikan berdasarkan kebutuhan dan potensi desa yang merupakan prakarsa masyarakat desa. Artinya usaha yang kelak akan diwujudkan adalah digali dari keinginan dan hasrat untuk menciptakan sebuah kemajuan di dalam masyarakat desa. 


\subsubsection{Indikator Peran, Ciri, dan Tujuan BUMDes}

Pendirian BUMDes sebagaimana disebut dalam Permendesa PDTT No. 4 Tahun 2015 tentang Pendirian, Pengurusan dan Pengelolaan, dan Pembubaran Badan Usaha Milik Desa, memiliki peran, cirri, dan tujuan sebagai berikut:

\section{A. Peran BUMDes}

1. Meningkatlan kesejahteraan masyarakat dan BUM Desa pemerintah desa.

2. Membantu melakukan pengawasan terhadap pelaksanaan penyelenggara kegiatan ekonomi desa.

3. Membantu pemerintah desa dalam upaya mengembangkan sumber sumber potensi alam dan manusia didesa untuk dikembangkan menjadi sumber sumber sumber ekonomi

4. Menjadi media pemerintah desa untuk mewujudkan mewujudkan rencana pembangunan khususnya dibidang ekonomi.

\section{B. Ciri Utama BUMDesa:}

1. Badan Usaha ini dimiliki oleh desa dan dikelola bersama

2. Modal bersumber dari desa sebesar $51 \%$ dan dari masyarakat sebesar $49 \%$ melalui penyertaan modal (saham atau andil)

3. Operasionalisasinya menggunakan falsafah bisnis yang berakar dari budaya lokal

4. Bidang usaha yang dijalankan berdasarkan pada potensi dan informasi pasar

5. Keuntungan yang diperoleh ditujukan untuk meningkatkan kesejahteraan anggota (Penyetara Modal ) dan masyarakat melalui kebijakan desa

6. Difasilitasi oleh Pemerintah Propinsi, Pemerintah Kabupaten dan Pemerintahan Desa.

7. Operasionalisasi di kontrol secara bersama oleh BPD, Pemerintah Desa dan Anggota).

\section{Tujuan Pendirian BUMDesa}

Empat tujuan penting pendirian BUMDesa adalah:

1. Meningkatkan Perekonomian Desa

2. Meningkatkan Pendapatan asli Desa

3. Meningkatkan Pengelolaan potensi desa sesuai dengan kebutuhan masyarakat

4. Menjadi tulang punggung pertumbuhan dan pemerataan ekonomi desa.

Untuk bisa mencapai empat tujuan BUMDesa diatas antara lain harus dilakukan dengan cara memenuhi kebutuhan (Produktif dan Konsumtif) masyarakat melalui pelayanan barang dan jasa yang dikelola oleh masyarakat dan pemerintah desa. Lembaga ini juga dituntut mampu memberikan pelayanan kepada non anggota (pihak luar Desa) dengan menempatkan harga dan pelayanan sesuai standar pasar. Artinya terdapat mekanisme 
kelembagaan yang disepakati bersama, sehingga tidak menimbulkan distorsi ekonomi pedesaan disebabkan oleh usaha BUMDesa.

\subsection{Ekonomi Masyarakat}

\subsubsection{Pengertian}

Menurut Mubaryo (2007:89) ekonomi masyarakat/kerakyatan adalah ekonomi yang demokratis yang ditujukan untuk kemakmuran rakyat kecil. Sedangkan ekonomi kerakyatan menurut Zulkarnain (2006:98) adalah suatu sistem ekonomi yang harus di anut sesuai dengan falsafah negara kita yang menyangkut dua aspek, yakni keadilan dan demokrasi ekonomi, serta keberpihakan kepada ekonomi rakyat. Sedangkan menurut A. Simarmata (2007:117) Istilah demokrasi ekonomi yang secara tegas terdapat pasal penjelasan, dapat ditafsirkan sebagai setara dengan ekonomi kerakyatan.

Berdasarkan pengertian di atas, maka dapat ditarik kesimpulan bahwa ekonomi kerakyatan adalah perkembangan ekonomi kelompok masyarakat yang mengikut sertakan seluruh lapisan masyarakat dalam proses pembangunan yang berkaitan erat dengan aspek keadilan, demokrasi ekonomi, keberpihakan pada ekonomi rakyat yang bertumpu pada mekanisme pasar yang adil dan mengikutsertakan seluruh lapisan masyarakat dalam proses pembangunan, serta berperilaku adil bagi seluruh masyarakat, dengan tujuan untuk peningkatan kesejahteraan ekonomi secara keseluruhan atau mayoritas masyarakat.

\subsubsection{Pendapatan Masyarakat}

Dalam kamus besar bahasa Indonesia pendapatan adalah hasil kerja (usaha atau sebagainya). Sedangkan pendapatan dalam kamus manajemen adalah uang yang diterima oleh perorangan, perusahaan dan organisasi lain dalam bentuk upah, gaji, sewa, ongkos, bunga, komisi, dan laba.

Pendapatan seseorang juga dapat didefinisikan sebagai banyaknya penerimaan yang dimulai dengan satuan mata uang yang dapat dihasilkan seseorang atau suatu bangsa dalam periode tertentu. Reksoprayitno mendefinisikan: "pendapatan (revenue) dapat diartikan sebagai total penerimaan yang diperoleh pada periode tertentu". Dengan demikian dapat disimpulkan bahwa pendapatan adalah sebagai jumlah penghasilan yang diterima oleh para anggota masyarakat untuk jangka waktu tertentu sebagai balas jasa atau faktor-faktor produksi yang telah disumbangkan. Pendapatan masyarakat adalah penerimaan dari gaji atau balas jasa dcari hasil usaha yang diperoleh individu atau kelempok rumah tangga dalam satu bulan dan digunakan untuk memenuhi kebutuhan sehari-hari. Sedangkan dari usaha sampingan adalah pendapatan tambahan yang merupakan penerimaan lain dari luar aktifitas pokok atau pekerjaan pokok. Pendapatan sampingan diperoleh secara langsung dapat digunakan untuk menunjang atau menambah pendapatan pokok.

Tingkat pendapatan masyarakat merupakan salah satu kriteria maju tidaknya suatu daerah. Bila pendapatan suatu daerah relatif rendah, dapat dikatakan bahwa kemajuan dan 
kesehjateraan tersebut akan rendah pula. Kelebihan dari konsumsi makan akan disimpan pada bank yang tujuannya adalah untuk berjaga-jaga apabila baik kemajuan dibidang pendidikan, produksi dan sebagainnya juga mempengaruhi tingkat tabungan masyarakat. Dengan demikian pula hanya bila pendapatan masyarakat suatu daerah relative tinggi, maka tingkat kesejahteraan dan kemajuan daerah tinggi pula.

\subsubsection{Prinsip-Prinsip Ekonomi Masyarakat / Rakyat}

Ekonomi kerakyatan sebagai sebuah sistem sudah barang tentu mempunyai prinsipprinsip dasar yang berbeda dengan sistem ekonomi lainnya. Secara umum para pakar ekonomi belum ada menyebutkan suatu prinsip yang utuh yang menyangkut dengan demokrasi ekonomi. Hanya saja di antara prinsip yang tertuang dalam UUD 1945 terutama pasal 33 adalah:

1. Prinsip kekeluargaan. dalam penjelasan UUD 1945 dinyatakan bahwa perekonomian disusun sebagai usaha bersama berdasarkan atas azas kekeluargaan. Prinsip ini merupakan acuan semua badan usaha baik BUMN dan BUMS, BUMD.

2. Prinsip keadilan. Pelaksanaan ekonomi kerakyatan harus bisa mewujudkan keadilan dalam masyarakat. Sistem ini diharapkan dapat memberikan peluang yang sama kepada semua anak bangsa, apakah ia sebagai konsumen, pengusaha maupun sebagai tenaga kerja. Tidak ada perbedaan suku, agama dan gender, semuanya sama dalam lapangan ekonomi.

3. Prinsip pemerataan pendapatan. Masyarakat sebagai konsumen dan pelaku ekonomi harus merasakan pemerataan pendapatan. Kalau selama ini pemerintah terlalu mementingkan pertumbuhan ekonomi yang tinggi teryata itu hanya semu belaka. Pertumbuhan yang tinggi tidak membawa pada pemerataan pendapatan. Pertumbuhan itu hanya dirasakan segelintir masyarakat yang disebut pengusaha besar, sementara mayoritas masyarakat berbeda pada posisi miskin dan melarat.

4. Prinsip keseimbangan antara kepentingan individu dan kepentingan masyarakat. Kegiatan ekonomi harus mampu mewujudkan adanya sinergi antara kepentingan individu dengan kepentingan masyarakat. Pada pasal 27 ayat 2 UUD 1945 menyatakan bahwa tiap-tiap warga negara berhak atas pekerjaan dan penghidupan yang layak bagi kemanusiaan.

Hal ini mengisyaratkan bahwa kepentingan pribadi/individu merupakan hal yang harus mendapat prioritas. Namun kepentingan pribadi/individu tidak boleh mengabaikan kepentingan masyarakat. Untuk menjaga kepentingan masyarakat negara memiliki kompetensi untuk menguasai berbagai cabang produksi yang dapat memenuhi kebutuhan hidup masyarakat banyak.

5. Prinsip kerja sama atau jaringan. Dalam prinsip ini para pelaku ekonomi harus saling membantu dan bekerja sama. Dengan kerja sama tentu berbagai kegiatan usaha kecil akan menjadi kuat dan besar.Kerja sama ini bisa menghimpun para pelaku ekonomi baik 
produsen, konsumen dan pelaku ekonomi lainnya, baik usaha besar, menengah ataupun kecil. Dengan dukungan informasi dan pembiayaan yang cukup maka UKM akan mampu bangkit dari keterbelakangan.

\subsection{Penelitian Terdahulu}

Dalam memperkuat penelitian ini diperlukan beberapa penelitian terdahulu yang relevan dan sesuai dengan bidang penelitian ini. Adapun penelitian sebelumnya sebagai berikut:

1) Iwan, Nawir dan Daud Yusuf (2013:11) pada penelitianya tentang Dampak BUMDES Aryasari di Desa Ayla Tilango Kecamatan Bulango Selatan Kabupaten Bone Bolango.menyimpulkan bahwa dengan adanya aktivitas BUMDES tingkat perekonomian masyarakat meningkat sebanyak $48 \%$ dan pengangguran berBUMDESang sebanyak $23 \%$.

2) Gian Yuniarto Wilo Harlan (2011:89) dalam penelitianya tentang Analisis Nilai Guna Ekonomi Dan Dampak adanya BUMDES Di Kecamatan Tamansari Kabupaten Bogor menyimpulkan beberapa simpulan yang salah satunya menatakan bahwa total nilai guna dari kegiatan BUMDes adalah sebesar 4.368.750.000.

3) Risyanto (2012:13) Pegaruh Keberadaan BUMDes terhadap kondisi sosial ekonomi di Kecamatan Kemalang Kabupaten Klaten, Provinsi Jawa Tengah menyimpulkan bahwa Perbedaan pendapatan sebelum-sesudah adalah Rp. 966.667.

\subsection{Kerangka Fikir}

Secara sederhana kerangka konseptual di dalam penelitian ini dapat dilihat dalam gambar 1 . berikut ini :

\section{Gambar 1. Kerangka Konseptual}

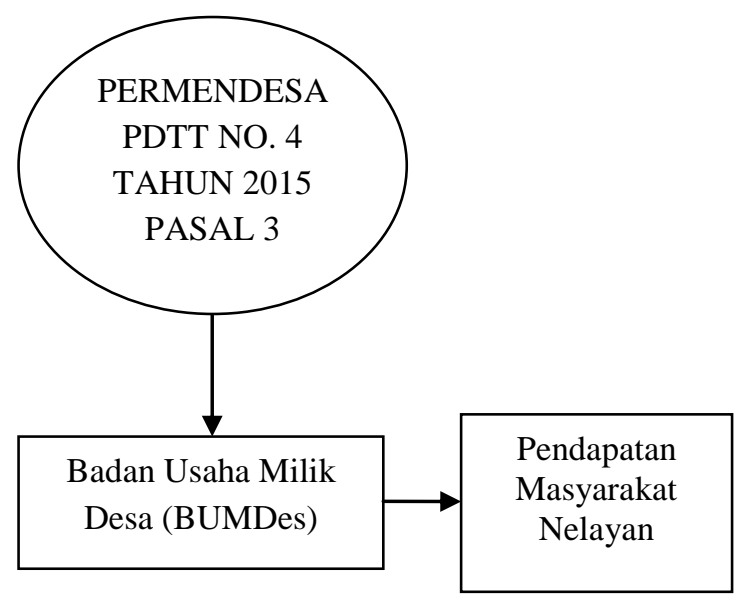




\section{METODE PENELITIAN}

\subsection{Teknik Pengumpulan Data}

Adapun teknik pengumpulan data yang penulis gunakan adalah studi pustka, wawancara dan dokumentasi.

\subsection{Teknik Analisis Data}

Menurut Arikunto (2010:361) diketahui bahwa analisis data diskriptif didekati dari dua sudut pendekatan, yaitu analisis diskriptif dan analisis data diskriptif inferensial. Dalam penelitian ini peneliti menggunakan teknik analisis data diskriptif.

\subsubsection{Analisis data Diskriptif}

Fungsi statistik deskriptif adalah selalu berhubungan dengan angka, baik angka yang diperoleh dari pencacahan maupun perhitungan. Data yang diperoleh selanjutnya diolah dan disajikan dalam bentuk yang lebih mudah dan lebih dimengerti oleh pengguna data tersebut

\subsubsection{Tahap Analisis Diskriptif}

Menurut Arikunto, (2010: 363) terdapat tahapan dalam Analisis Diskriptif yakni:

1) Menentukan jenis data

2) Jika peneliti mempunyai data diskrit, penyajian data yang dapat dilakukan adalah mencari frekuensi mutlak, frekuensi relatif (mencari persentase), serta mencari uBUMDESan tendensi sentralnya yaitu: mode, median dan mean.

Dalam penelitian ini tahapan untuk menganalisis data dilakukan dengan cara sederhana karna data yang diperoleh sudah terklasifikasikan dan kualifikasikan. Sehingga peneliti mulai bisa bicara sesuai dengan keadaan yang termuat didalamnya. Pada penelitian ini peneliti akan menggambarkan atau mendiskripsikan data yang ada dalam pentuk chart, tabel, digram dan grafik agar mempermudah pembaca dalam memahami hasil analisis data yang diperoleh.

\section{HASIL PENELITIAN DAN PEMBAHASAN}

Berdasarkan data diatas maka peneliti akan menggunakan program SPSS16.0 untuk mendiskripsikan data perubahan sebelum dan sesudah penutupan tambang pasir pada desa Sukorahayu kecamatan Labuhan Maringgai adalah sebagai berikut:

Tabel 1. Diskriptif Statistik

\begin{tabular}{|l|r|c|c|c|c|c|}
\hline & \multicolumn{1}{c|}{ D } & Minimum & Maximum & \multicolumn{2}{c|}{ Mean } & Std. Deviation \\
\cline { 2 - 7 } & Statistic & Statistic & Statistic & Statistic & Std. Error & Statistic \\
\hline $\begin{array}{l}\text { Peningkatan } \\
\text { Valid N } \\
\text { (listwise) }\end{array}$ & 85 & 2000000.00 & 95000000.00 & 14682926.8293 & 2060210.65574 & 18656000.95344 \\
\hline
\end{tabular}

Sumber: spss 16.0

8 Jurnal Fidusia $\sim$ Volume 2, Nomor 2, November 2019 
Berdasarkan data diatas terlihat peningkatan minimum sebesar Rp 2000.000 sementara data maksimum perubahan peningkatan pendapatan sebesar Rp. 95000000 sementara mean atau data rata rata peningkata pendapatan dengan adanya dana BUMDES sebesar 14.682.926,8293.

Tabel.2 Total Pendapatan Masyarakat Nelayan Yang Menggunakan Dana BUMDES

\begin{tabular}{|r|c|l|l|c|c|}
\hline \multirow{2}{*}{$\begin{array}{c}\text { Jumlah } \\
\text { Responden }\end{array}$} & \multirow{2}{*}{$\begin{array}{c}\text { Total } \\
\text { Pinjaman }\end{array}$} & $\begin{array}{l}\text { Sebelum } \\
\text { Menggunakan } \\
\text { dana } \\
\text { BUMDES }\end{array}$ & $\begin{array}{l}\text { Sesudah } \\
\text { Menggunakan } \\
\text { dana } \\
\text { BUMDES }\end{array}$ & $\begin{array}{c}\text { Total } \\
\text { Peningkatan }\end{array}$ & \multirow{2}{*}{} \\
\hline 85 & 813000000 & 2280000000 & 3501000000 & 1221000000 & $53.60 \%$ \\
\hline
\end{tabular}

Sumber: Arsip BUMDES Sukorahayu

Berdasarkan data diatas dapat terlihat total peningkatan pendapatan sebanyak Rp. 1.221.000.000 dengan total pinjaman Rp. 813.000.000. dan berdasarkan peningkatan sebesar $53.6 \%$ dari pendapatan sebelum menggunakan dana BUMDES. Sehingga dapat diketahui bersama bahwa dana BUMDES berperan penting dalam meningkatkan pendapatan masyarakat desa Sukorahayu.

\subsubsection{Grafik Peningkatan Pinjaman Dan Pendapatan Nalayan Selama Bumdes Berdiri}

Tabel.3 Total Pendapatan Masyarakat Nelayan Yang Menggunakan Dana BUMDES

\begin{tabular}{|c|c|c|c|c|c|c|}
\hline \multirow[b]{2}{*}{ Tahun } & \multirow[b]{2}{*}{$\begin{array}{c}\text { Jumlah } \\
\text { Responden }\end{array}$} & \multirow[b]{2}{*}{$\begin{array}{c}\text { Total } \\
\text { Pinjaman }\end{array}$} & \multicolumn{2}{|c|}{ Total pendapatan } & \multirow[b]{2}{*}{$\begin{array}{c}\text { Total } \\
\text { Peningkatan }\end{array}$} & \multirow[b]{2}{*}{ Presentase } \\
\hline & & & $\begin{array}{c}\text { Sebelum } \\
\text { Menggunakan } \\
\text { dana } \\
\text { BUMDES }\end{array}$ & $\begin{array}{c}\text { Sesudah } \\
\text { Menggunakan } \\
\text { dana BUMDES }\end{array}$ & & \\
\hline 2015 & 57 & 375000000 & 960300000 & 1420000000 & 459700000 & $48 \%$ \\
\hline 2016 & 68 & 591000000 & 1270000000 & 1932000000 & 662000000 & $52 \%$ \\
\hline 2017 & 85 & 813000000 & 2280000000 & 3501000000 & 1221000000 & $54 \%$ \\
\hline
\end{tabular}

Berdasarkan tabel diatas diketahui bahwa selama tahun 2015 hingga 2017 presentase peningkatan pendapatan nelayan mengalami kenaikan yang relative meski belum terlalu signifikan, Adapaun peningkatan tertinggi berada pada tahun 2018 yang memiiki presentase peningkatan sebesar 54\% dengan jumlah peningkatan Rp.122.100.000. dengan total pinjaman Rp.813.000.000. Dengan demikian keberadaaan BUMDes Sukorahayu memberikan dampak positif yang signifikan terhadap pendapatan nelayan selama berdiri 3tahun. 
Gambar 2 Grafik Penigkatan Pendapatan Nalayan

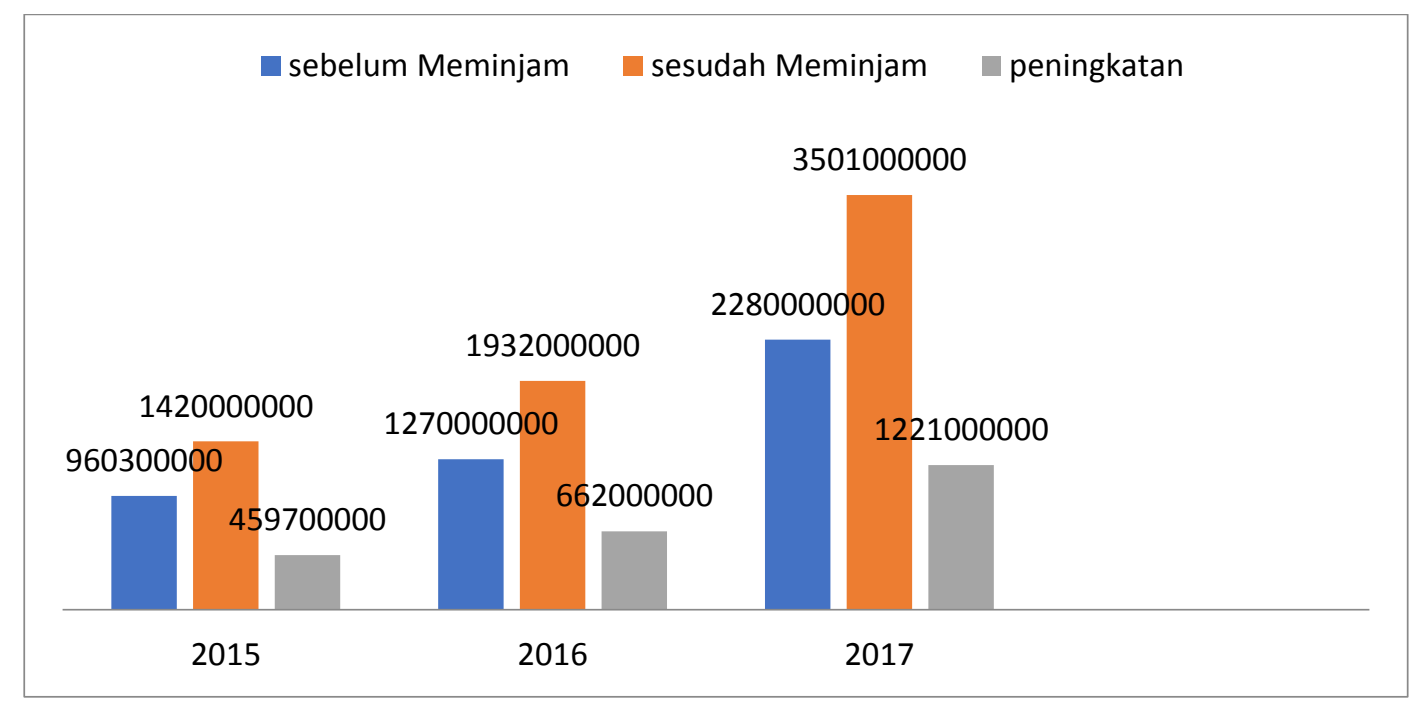

Sumber: analisis data

Berdasarkan pada grafik terlihat dengan jelas terdapat peningkatan pendapatan nelayan dari than 2015 hingga 2017, dengan total peningkatan tertinggi ada pada tahun 2017 sebanyak Rp. 1.221.000.000, sementara pendapatan terendah ada pada tahun 2015 yakni sebanyak Rp. 459.700.000; hal ini dikarenakan masih baru merintis dan awalnya program simpan pinjam yang diadakan oleh BUMDes Sukorahayu.

\section{KESIMPULAN DAN SARAN}

\section{1). KESIMPULAN}

Berdasarkan hasil analisis yang telah dilakukan, dapat ditarik kesimpulan sebagai berikut :

Berdasarkan hasil penelitian yang diperoleh peneliti menyimpulkan bahwa peningkatan minimum sebesar Rp 2000.000 sementara data maksimum perubahan peningkatan pendapatan sebesar Rp. 95.000.000 sementara mean atau data rata rata peningkata pendapatan dengan adanya dana BUMDES sebesar 14.682.926,00. Sementara total peningkatan pendapatan sebanyak Rp. 1.221.000.000 dengan total pinjaman Rp. 813.000.000. dan berdasarkan peningkatan sebesar $53.6 \%$ dari pendapatan sebelum menggunakan dana BUMDES. Sehingga dapat diketahui bersama bahwa dana BUMDES berperan penting dalam meningkatkan pendapatan masyarakat Nelayan desa Sukorahayu.

\section{2) SARAN}

1. Bagi Desa Sukorahayu

Disarankan agar seluruh masyarakat nelayan Desa Sukorahayu dapat lebih aktif dan kreatif dalam meningkatkan produktivitas usaha yang dilakukan. 
2. Bagi Pemerintah

Diharapkan pemerintah dapat lebih mensupport program pendanaan terhadap BUMDES untuk terus meningkatkan pendapatan masyarakat, sehingga dapat tercapai ekonomi masyarakat yang sejahtera.

\section{DAFTAR PUSTAKA}

A. Simarmata,2008.Reformasi Ekonomi, Jakarta : Lembaga Penerbit Fakultas Ekonomi UI. Ahmad Rivai.2008.Kredit dana agunan .Semarang:Badan PenerbitUniversitas Diponogoro.

Andriani, S, 2008. Analisis Faktor-Faktor Yang Mempengaruhi Volume Penyaluran Kredit Mikro, Kecil Dan Menengah (MKM) Di Indonesia. Skripsi Pada Departemen Ilmu Ekonomi. Fakultas Ekonomi dan Manajemen, Institut Pertanian Bogor.

Gian Yuniarto Wilo Harlan (2011) Analisis Nilai Guna Ekonomi Dan Dampak adanya

BUMDES Di Kecamatan Tamansari Kabupaten Bogor. Bogor: Tesis Instiut Pertanian Bogor

Iwan, Nawir dan Daud Yusuf.(2013). Damapak Aktivitas BUMDES Arya di Desa Ayla Tilango Kecamatan Bulango Selatan Kabupaten Bone Bolango.Semarang:Undip.ac.id

Muhammad, Abdulkadir dan Rilda Murniati, 2000. Lembaga Keuangan dan Pembiayaan, PT Citra Aditya Bakti, Bandung.

Mubaryo, 2009. Manajemen Perkreditan Bagi Bank Komersial, Cetakan Ke- 3, BPFE Yogyakarta, Yogyakarta.

Pinem, J, 2011. Implementasi Kredit Usaha Rakyat Dalam Mengembangkan Usaha Kecil. Skripsi pada Departemen Ilmu Sosial dan Ilmu Politik. Fakultas Ilmu Sosial dan Ilmu Politik, Universitas Sumatera Utara.

Pudjo Muljono, Teguh, 2001. Manajemen Perkreditan Bagi Bank Komersial, Cetakan Ke- 3, BPFE Yogyakarta, Yogyakarta.

Raka, Hubies 2009.Analisis peranan UMKM Masyarakat . Semarang: Badan Penerbit Universitas Diponogoro.

Risyanto.2012.Pengaruh keberadaan BUMDES terhadap kondisios sosial ekonomi di Kecamatan Kemalang kabupaten Jawa Tengah. Yogyakarta:UGM.ac.id

Sari, F, 2011. Peran Koperasi Simpan Pinjam Dalam Perkembangan UMKM Agribisnis Di

Bogor. Skripsi pada Departemen Agribisnis. Fakultas Ekonomi dan Manajemen,Institut Pertanian Bogor.

Siamat, Dahlan, 2009. Manajemen Lembaga Keuangan. Intermedia, Jakarta.

Simamarta, ahmad, 2007. Manajemen Perkreditan Bagi Bank Syariah, Cetakan Ke- 3, BPFE Yogyakarta, Yogyakarta.

Sukirno.2008.analisis pengangguran didesa rejoayu kecaamatan sukorahayu. Skripsi pada Departemen Agribisnis. Fakultas Ekonomi dan Manajemen,Institut Pertanian Bogor. Suharto.2008. Kredit dana agunan. Semarang: Badan Penerbit Universitas Diponogoro. 
Suharsimi Arikunto. (2010). Prosedur penelitian edisi revisi . Jakarta: Rineka Cipta.

Wahyuni, Eti, dkk, 2008. Lilitan Masalah Usaha Mikro, Kecil, Menengah (UMKM) \& Kontroversi Kebijakan, BITRA Indonesia, Medan. http:/www.galeriukm.web.id/news/kriteria-usaha-mikro-kecil-dan-menengah-umkm (10 Juni 2012)

http://komite-BUMDES.com/cetak-51-sebaran-BUMDES-november-2007-sd-desember2011.asp (14 Juni 2012) http:/www.bi.go.id/NR/rdonlyres/DDE3BFBD3879/Suplemen4.pdf (14 Juni 2012)

Undang - Undang Dasar 1945 pasal 33 